\title{
New Insights in Bladder Cancer Diagnosis: Urinary miRNAs and Proteins
}

\author{
Gökçe Güllü Amuran ${ }^{1}$, Irem Peker Eyuboglu ${ }^{1}$, Ilker Tinay ${ }^{2}$ and Mustafa Akkiprik ${ }^{1, *(\mathbb{C})}$ \\ 1 Department of Medical Biology, School of Medicine, Marmara University, Istanbul 34899, Turkey; \\ gokcegullu@gmail.com (G.G.A.); pekerirem@gmail.com (I.P.E.) \\ 2 Department of Urology, School of Medicine, Marmara University, Istanbul 34854, Turkey; \\ itinay@marmara.edu.tr \\ * $\quad$ Correspondence: makkiprik@marmara.edu.tr; Tel.: +90-216-421-22-22; Fax: +90-216-414-47-31
}

Received: 21 September 2018; Accepted: 3 December 2018; Published: 7 December 2018

\begin{abstract}
Bladder cancer is the 10th-most common cancer worldwide. The diagnosis and follow-up of patients require costly invasive methods and due to these expenses, bladder cancer continues to be one of the expensive malignancies. Early diagnosis is crucial in bladder cancer as it is in other cancers; therefore, non-invasive biomarkers for early diagnosis are very important. In this review, we aimed to focus on the most recent investigations on potential urinary micro RNA (miRNA) and protein biomarkers for bladder cancer diagnosis and their associated pathways. Studies performed by different groups were compiled and the biomarker properties of various proteins and miRNAs in the urine of bladder cancer patients were evaluated. Key studies were obtained by searching keywords "bladder cancer, urinary miRNA, urinary protein, urinary biomarker". Targets and the pathways of the miRNAs and proteins were analyzed according to mirBase Catalogue and Panther Database. The major pathways that are targeted by aberrantly expressed miRNAs are Cholecystokinin receptor $(C C K R), p 53$, Wnt signaling pathway, and feedback loops. We hereby conclude that urinary micro RNAs and proteins are promising candidates for bladder cancer diagnosis. It should be noted that urine collection, storage conditions, choice of fraction, and normalization strategies should be standardized.
\end{abstract}

Keywords: bladder cancer; urinary biomarkers; micro RNA (miRNAs); urinary proteins; cholecystokinin receptor pathway; $p 53$ pathway

\section{Introduction}

Cancer is the leading cause of death and a major health problem worldwide. According to the Global Cancer Observatory (GLOBOCAN) database, bladder cancer (BC) is the 10th-most frequently detected cancer in both sexes and 9th-most lethal malignancy in men [1]. When detected early in the non-muscle invasive (NMI) stage, the five-year survival rates of $\mathrm{BC}$ are $>90 \%$; however, the diagnosis of NMI disease requires close follow-up with potential further treatments, given that five year non-muscle-invasive bladder cancer (NMIBC) recurrence rates range from $50 \%$ to $70 \%$, and progression to muscle invasive disease range from $10 \%$ to $30 \%$ [1].

The gold standard for $\mathrm{BC}$ follow-up is cystoscopy and it should be performed every three months for the first two years, every six months for the next two years and then every year according to clinical judgment and patient's preference for muscle invasive bladder cancer (MIBC) patients [2]. Although the sensitivity of cystoscopy is $90 \%$ for diagnosis, it is an invasive procedure and small tumors can be missed. The diagnosis and follow-up of patients require costly invasive methods and due to these, bladder cancer continues to be one of the most expensive malignancies [3]. Therefore, the discovery and utility of urine-based non-invasive markers for the diagnosis and follow-up of bladder cancer might 
help to prevent the patient from periodically experiencing the physical, mental, and economic burden of cystoscopy. Since cystoscopy is considered as the gold standard in the diagnosis, the sensitivity and specificity of candidate biomarkers in the literature are generally evaluated by comparison with cystoscopy. New biomarker detection studies are usually aimed to reach or exceed the sensitivity and specificity of cystoscopy.

Micro RNAs (miRNAs) and proteins that reflect the properties of BC can be found in urine samples of $B C$ patients. There are various studies on urine bladder cancer biomarkers but the relationship between these needs further study [4,5]. There are currently six Food and Drug Administration (FDA) approved tests for clinical use. These are bladder tumor antigen (BTA) stat, BTA TRAK, nuclear matrix protein 22 (NMP22), NMP22 BladderCheck Test, uCyt, and UroVysion tests. The sensitivity of these kits for bladder cancer diagnosis ranges from $57-82 \%$ to $74-88 \%$ and the sensitivity increases as the stage and degree of cancer increases. These tests are not used for diagnostic purposes alone without cystoscopy, since they cannot beat the cystoscopy with a sensitivity of $98 \%$ [6].

Nuclear matrix protein 22 (NMP22) BC test kit is an enzyme-linked immunosorbent assay (ELISA) based kit that detects NMP22 in urine samples of patients, BTA STAT and Trak kits are designed to detect BTA in voided urine samples. The (uCyt+) ImmunoCyt test detects exfoliated BC cells in the urine by using fluorescent monoclonal antibodies against to a high-molecular-weight form of carcinoembryonic antigen (M344) and bladder tumor cell-associated mucins (LDQ10 and 19A11) [7,8]. UroVysion bladder cancer kit detects chromosome 3, 7, 17 aneuploidies and loss of the 9p21 locus via fluorescence in situ hybridization (FISH) in urine specimens [9]. These methods are either highly sensitive or specific, but never both.

miRNAs are small, 20-24 nucleotides long non-protein coding RNA gene products that mediate target messenger RNA (mRNA) degradation or translational repression and they can serve as oncogenes or tumor suppressors. They can be extracted from a wide range of biological samples such as blood plasma, urine, feces, or biopsy specimens and are generally stable and resistant to various storage conditions. Changes in miRNAs can be detected non-invasively and quantified in body fluids using highly sensitive and standardized techniques. Therefore, miRNAs are good candidates for molecular markers of diagnosis, prognosis, and clinical follow-up [10].

In this review, we will focus on urinary extracellular protein and microRNA biomarkers that will open doors to non-invasive procedures for diagnosis and prognosis of bladder cancer. Evidences were achieved by searching PubMed, Medline, Google Scholar, and Web of Science Core Collection using keywords "bladder cancer, urinary miRNA, urinary protein, urinary biomarker". Experimentally identified targets and pathways were analyzed according to mirBase Catalogue and Panther Database.

\section{Urinary Proteins for Bladder Cancer Diagnosis}

Several differences were observed among the protein expressions in urine samples of healthy individuals and patients with bladder cancer. Table 1 summarizes the putative BC biomarkers in urine samples. Among them, Apo-A1, IL-8, MMP-9, MMP-10, PAI-1, CD44, VEGF, ANG, CA9, OPN, PTX3, APOE, AGR2, and soluble Fas are considered as candidate biomarkers for bladder cancer [4,5,11-13]. Soluble urinary proteins could be measured in the urine supernatant using inexpensive, rapid, and qualitative immunoassays such as ELISA. Most of the studies focus on FDA approved molecules such as NMP22, BTA, UroVysion, ImmuoCyt but there are also some acknowledged biomarkers such as apolipoprotein A4, Anteriorgradient 2, calprotectin, clusterin, coronin-1A, fibronectin, reg-1, stathmin-1, and $\gamma$-synuclein $[12,14]$.

Anteriorgradient 2 (AGR2) is a cancer related secreted protein mainly found in adenocarcinomas. Anteriorgradient 2 is found ubiquitously in solid tumors and it can be a valuable biomarker in urine or blood for early diagnosis. Noncancerous organs also express, but not secrete AGR2, while cancer cells secrete AGR2. Anteriorgradient 2 is also found on the cell surface of cancer cells. When taken together, AGR2 secretion and cell surface localization are characteristics of cancer, whereas AGR2 expression alone is not. An ideal biomarker should have properties to distinguish cancer cells from healthy cells 
and AGR2 can do it via localization and secretion. It has been found that normal bladder urothelial cells show uniform immunostaining with moderate intensity for AGR2 [12].

Table 1. Urinary proteins for bladder cancer diagnosis.

\begin{tabular}{|c|c|c|c|}
\hline Abbreviation & Name & $\begin{array}{l}\text { Cellular Function and } \\
\text { Pathway }\end{array}$ & Concentration in BC Urine Samples \\
\hline A1AT/(SERPINA1) & $\begin{array}{l}\text { Serpin family A } \\
\text { member } 1\end{array}$ & $\begin{array}{l}\text { Complement and } \\
\text { coagulation cascades [15]. }\end{array}$ & $\begin{array}{l}\text { Both ELISA and Multi-array assay revealed } \\
\text { that candidates including A1AT could } \\
\text { discriminate BC patients from controls, NMIBC } \\
\text { from MIBC [16]. Strongly correlated with } \\
\text { urinary hemoglobin (Spearman's correlation } \\
\text { coefficient }>0.8 \text { ), so the increase in } \\
\text { concentration in BC patients' urine samples } \\
\text { may be due to hematuria [11]. }\end{array}$ \\
\hline ANG & Angiogenin & Angiogenesis [17]. & $\begin{array}{l}\text { Urinary concentrations of } A N G \text { were } \\
\text { significantly elevated in subjects with BC } \\
\text { compared to controls [18]. Both ELISA and } \\
\text { Multi-array assay revealed that candidates } \\
\text { including ANG could discriminate BC patients } \\
\text { from controls, NMIBC from MIBC [16]. }\end{array}$ \\
\hline Apo-A1 & Apolipoprotein A1 & $\begin{array}{l}\text { Lipid metabolism and } \\
\text { transport [19]. }\end{array}$ & $\begin{array}{l}\text { Increased in urine samples of aggressive } \\
\text { Bladder transitional cell carcinoma (BTCC) } \\
\text { compared to low malignant BTCC [5]. } \\
\text { Western blot analysis and ELISA assays also } \\
\text { revealed that candidates including Apo-A1 } \\
\text { levels in urine samples of BC patients were } \\
\text { significantly elevated [4]. }\end{array}$ \\
\hline$A P O E$ & Apolipoprotein E & $\begin{array}{l}\text { Transport of cholesterol and } \\
\text { other lipids [20] }\end{array}$ & $\begin{array}{l}\text { Urinary concentrations of } A P O E \text { were } \\
\text { significantly elevated in subjects with BC } \\
\text { compared with controls but diagnostic } \\
\text { performance of } A P O E \text { as a single biomarker } \\
\text { was not sufficient }[11,21] \text {. APOE levels were } \\
\text { significantly increased in high compared to low } \\
\text { grade tumors as well as in MIBC compared to } \\
\text { NMIBC, both ELISA and Multi-array assay } \\
\text { revealed that APOE could discriminate BC } \\
\text { patients from controls }[16,18] \text {. }\end{array}$ \\
\hline BTA/hCFHrp & $\begin{array}{l}\text { complement factor } \\
\text { H-related protein }\end{array}$ & $\begin{array}{l}\text { Involved in complement } \\
\text { regulation. }\end{array}$ & $\begin{array}{l}\text { Urinary concentrations of BTA were } \\
\text { significantly elevated in subjects with } \\
\text { BC }[10,11,22-25] .\end{array}$ \\
\hline CA9 & carbonic anhydrase 9 & $\begin{array}{l}\text { Involved in pH regulation, } \\
\text { control of cell proliferation } \\
\text { and transformation [26]. } \\
\text { There are also studies } \\
\text { advocating axiom. }\end{array}$ & $\begin{array}{l}\text { Urinary concentrations of } C A 9 \text { were } \\
\text { significantly elevated in subjects with } \\
\text { BC }[11,24] . \text { But some studies advocating the } \\
\text { opposite [18]. }\end{array}$ \\
\hline CCL18 & $\begin{array}{l}\mathrm{C}-\mathrm{C} \text { motif chemokine } \\
\text { ligand } 18\end{array}$ & $\begin{array}{l}\text { Involved in } \\
\text { immunoregulatory and } \\
\text { inflammatory processes [27]. }\end{array}$ & $\begin{array}{l}\text { Urinary concentrations were significantly } \\
\text { elevated in subjects with BC [22]. The } \\
\text { concentrations of CCL18 in urine samples are } \\
\text { correlated with hemoglobin, so the increase in } \\
\text { concentration in } B C \text { patients' urine samples } \\
\text { may be due to hematuria [11]. }\end{array}$ \\
\hline$C D 44$ & $\begin{array}{l}\text { CD44 antigen } \\
\quad \text { (Epican) }\end{array}$ & $\begin{array}{l}\text { Cell-surface glycoprotein, } \\
\text { involved in cell-cell } \\
\text { interactions, cell adhesion } \\
\text { and migration [28]. }\end{array}$ & $\begin{array}{l}\text { Urinary concentrations of CD44 were } \\
\text { significantly decreased in subjects with BC [11]. } \\
C D 44 \text { improved the prediction power of CCL18, } \\
\text { PAI-1 (AUC }=0.938)[22] .\end{array}$ \\
\hline$I L-8$ & Interleukin-8 & $\begin{array}{l}\text { Chemotactic factor, released } \\
\text { from several cell types in } \\
\text { response to an inflammatory } \\
\text { stimulus [29]. }\end{array}$ & $\begin{array}{l}\text { Group of proteins, including } I L-8 \text {, had } \\
\text { significantly higher expression in BC subjects, } \\
I L-8 \text { was the most consistent one, multivariate } \\
\text { regression analysis revealed that only } I L-8 \text { was } \\
\text { an independent factor for the detection of } \\
\text { BC [25]. Urine } I L-8 \text { levels were significantly } \\
\text { increased in high compared to low-grade } \\
\text { tumors as well as in MIBC compared to } \\
\text { NMIBC. } I L 8 \text { could discriminate BC patients } \\
\text { from controls, low grade BC from high grade } \\
\text { BC, NMIBC from MIBC [18]. }\end{array}$ \\
\hline
\end{tabular}


Table 1. Cont.

\begin{tabular}{|c|c|c|c|}
\hline Abbreviation & Name & $\begin{array}{l}\text { Cellular Function and } \\
\text { Pathway }\end{array}$ & Concentration in BC Urine Samples \\
\hline$M M P-10$ & $\begin{array}{l}\text { Stromelysin-2/Matrix } \\
\text { metalloproteinase-10 }\end{array}$ & $\begin{array}{l}\text { Breakdown of extracellular } \\
\text { matrix [30]. }\end{array}$ & $\begin{array}{l}\text { Significantly higher expression was detected in } \\
\text { urine samples of bladder cancer patients } \\
\text { compared to healthy controls }[11,18] \text {. } \\
\text { Both ELISA and Multi-array assay revealed } \\
\text { that } M M P-10 \text { could discriminate BC patients } \\
\text { from controls, low grade BC from high grade } \\
\text { BC, NMIBC from MIBC [16]. }\end{array}$ \\
\hline$M M P-9$ & $\begin{array}{l}\text { Matrix } \\
\text { metalloproteinase-9 }\end{array}$ & $\begin{array}{l}\text { Involved in breakdown of } \\
\text { extracellular matrix and in } \\
\text { leukocyte migration [31]. }\end{array}$ & $\begin{array}{l}\text { Significantly higher expression was detected by } \\
\text { ELISA in urine samples of bladder cancer } \\
\text { patients compared to healthy controls [11]. } \\
\text { Both ELISA and Multi-array assay revealed } \\
\text { that } M M P-9 \text { could discriminate BC patients } \\
\text { from controls, NMIBC from MIBC [16]. } \\
\text { Biomarker levels were also compared with } \\
\text { respect to tumor grade and stage. IL-8, MMP-9, } \\
P A I-1 \text { and } A P O E \text { were significantly increased in } \\
\text { high compared to low grade tumors as well as } \\
\text { in MIBC compared to non-MIBC [18]. }\end{array}$ \\
\hline OPN (SPP1) & Osteopontin & $\begin{array}{l}\text { Appears to be involved in } \\
\text { tumorigenesis, metastasis, } \\
\text { Cell-matrix interaction and } \\
\text { type } 1 \text { immunity [32]. }\end{array}$ & $\begin{array}{l}\text { Urinary concentrations of } O P N \text { were } \\
\text { significantly elevated in subjects with BC [11]. }\end{array}$ \\
\hline PAI-1 (SERPINE1) & $\begin{array}{l}\text { Plasminogen activator } \\
\text { inhibitor-1 }\end{array}$ & $\begin{array}{l}\text { Inhibitor of fibrinolysis. } \\
\text { High expressions are } \\
\text { associated with } \\
\text { thrombophilia [33]. }\end{array}$ & $\begin{array}{l}\text { Urinary concentrations of CCL18, PAI-1, and } \\
\text { BTA were significantly elevated in subjects with } \\
\text { BC [22]. Urinary concentrations of } 14 \\
\text { biomarkers including PAI-1 were significantly } \\
\text { elevated in subjects with BC [11]. } \\
\text { Both ELISA and Multi-array assay revealed } \\
\text { that PAI1 could discriminate BC patients from } \\
\text { controls, low grade BC from high grade BC, } \\
\text { NMIBC from MIBC, PAI-1 was the most } \\
\text { accurate single biomarker for BC followed } \\
\text { closely by urinary IL8 [16]. }\end{array}$ \\
\hline PTX3 & Pentraxin 3 & $\begin{array}{l}\text { Expressed in numerous } \\
\text { tissues, such as monocytes, } \\
\text { dendritic cells, takes role in } \\
\text { inflammation [34]. }\end{array}$ & $\begin{array}{l}\text { Urinary concentrations of PTX3 were } \\
\text { significantly elevated in subjects with BC [11]. } \\
\text { PTX concentration in urine samples analyzed } \\
\text { by ELISA but no significant difference found } \\
\text { between BC and controls [23]. }\end{array}$ \\
\hline Scd-1 & Syndecan-1 & $\begin{array}{l}\text { Involved in cytoskeleton } \\
\text { regulation and exosome } \\
\text { biogenesis [35]. }\end{array}$ & $\begin{array}{l}\text { Elevated in the urine samples of BC patients } \\
\text { but results were not consistent. Any significant } \\
\text { association between cancer, control or stage } \\
\text { found }[11,16,36] \text {. }\end{array}$ \\
\hline sFAS & Soluble Fas & $\begin{array}{l}\text { Prevents apoptosis } \\
\text { induction, and enhances the } \\
\text { immunosuppressive effects } \\
\text { of tumors [37]. }\end{array}$ & $\begin{array}{l}\text { The urinary sFas levels were significantly } \\
\text { higher in the patients with UC than in those } \\
\text { without cancer [37], significantly elevated in } \\
\text { the NMIBC cases with a higher stage or grade } \\
\text { or high-risk group category than in those with } \\
\text { a lower stage or grade or low-risk group } \\
\text { category [38]. }\end{array}$ \\
\hline VEGF & $\begin{array}{l}\text { Vascular endothelial } \\
\text { growth factor }\end{array}$ & $\begin{array}{l}\text { Active in angiogenesis, } \\
\text { vasculogenesis and } \\
\text { endothelial cell growth [39]. }\end{array}$ & $\begin{array}{l}\text { Urinary concentrations significantly elevated in } \\
\text { subjects with BC [11]. VEGF was the most } \\
\text { accurate urinary biomarker [24] and could } \\
\text { discriminate BC patients from controls, NMIBC } \\
\text { from MIBC [16]. }\end{array}$ \\
\hline
\end{tabular}

BC: Bladder cancer; NMIBC: Non muscle invasive bladder cancer; MIBC: Muscle invasive bladder cancer;

UC: Urothelial cancer.

Small amounts of AGR2 are secreted by urothelial cells, but it is not detectable in urine, hence the healthy human urine proteome does not include AGR2. Similarly, the blood proteome of healthy individuals does not contain a significant peptide count for AGR2, suggesting little urothelial secretion to the capillaries of lamina propria. Anteriorgradient 2 expression disappears in urothelial carcinoma (UC) and only $25 \%$ of primary tumors were observed to preserve AGR2 expression in a cohort of lymph node positive cases. Anteriorgradient 2 secretion and cell surface localization are characteristics of cancer, whereas AGR2 expression alone is not [12]. 
Urinary protein levels of FGFR3 and Cyclin D3 were analyzed by Western blotting in 321 bladder cancer follow-up patients and 150 healthy control samples. Urine FGFR3/Cyclin D3 expression analysis showed same detection rates with cytology/cystoscopy. The sensitivity and specificity of cytology / cystoscopy was $80 \%$ and $84 \%$ respectively, and 73\% and 90\% for FGFR3/Cyclin D3 [13].

Pterin compounds are considered to be biomarkers for various cancers due to their high expression levels in cancer samples. Six pterin metabolites in urine of 35 healthy control samples and 46 bladder cancer samples were analyzed using high performance liquid chromatography (HPLC). Pterin compound concentrations in bladder cancer patients were found to be higher than normal patients, but only two metabolites (xanthopterin and isoxanthopterin) showed statistically significant change between two groups [40]. The same research group found that the urinary APOA1 and APOA2 levels in bladder cancer samples were higher than the levels established in control samples [4,41,42]. Apolipoproteins were analyzed with an immunoassay for multiplexed detection of APOA1, APOA2, $\mathrm{APOB}, \mathrm{APOC} 2, \mathrm{APOC} 3$, and $\mathrm{APOE}$, and all six proteins were found to be significantly elevated in urine samples of $\mathrm{BC}$ patients when compared to controls (hernia patient volunteers). Immunoassay analysis revealed that all six proteins could be used as an urinary $\mathrm{BC}$ biomarker but five of the proteins, not APOE, could be used as an early diagnosis marker [42]. The protein biomarker panel (IL8, MMP-9, MMP-10, ANG, APOE, SDC1, A1AT, PAI1, CA9, and VEGFA) that includes APOE was analyzed in the urine samples of Japanese BC patients. Urinary biomarker concentrations were significantly elevated in BC samples, high-grade and muscle-invasive tumors. APOE, as a single biomarker, was not sufficient for diagnosis of $\mathrm{BC}$, but a 10-biomarker panel enabled to discriminate patients with $\mathrm{BC}$ area under the curve $(\mathrm{AUC})=0.892$, sensitivity $=0.85$ and specificity $=0.81$, respectively). A predictive model trained on the larger institutional cohort correctly identified $99 \%$ of the cases [43].

Fei and colleagues quantified ORM1 protein in urine samples of 186 bladder cancer patients and found that urinary ORM1-Cr was higher in bladder cancer patients compared to controls $(p<0.0001)$. They suggest that increased level of urinary ORM1 protein might be a useful biomarker for bladder cancer diagnosis [44].

An ELISA based case-control study revealed that the APE1/Ref-1 levels in urine samples could be a valid and reliable biomarker for BC. Urine APE1/Ref-1 levels of 169 Bladder Cancer patients and 108 healthy controls were analyzed and it has been found that APE1/Ref-1 levels were significantly elevated in cancer samples relative to the healthy controls and correlated with tumor grade and stage. Moreover, high APE1/Ref-1 levels were found in samples of patients with recurrence history of BC [45].

Nuclear matrix proteins (NMPs) play important roles in nuclear structure and function, especially during cell mitosis. Nuclear matrix protein 22 has been found to be shed into the urine of patients with bladder cancer at significantly higher concentrations compared to healthy controls [46]. Nuclear matrix protein 22 is a ubiquitous protein, not limited to malignant cells, that can be released into the urine from dead or dying urothelial cells and can subsequently lead to false positive results in response to other benign conditions such as infection, stones, and hematuria. Nevertheless, in the nomograms based on the NMP22 test, the AUC is higher than nomograms based on cytology (0.82 vs. 0.75) [47]. Nuclear matrix protein 22 was found to be useful in deciding between prompt and delayed cystoscopy in a decision curve analysis, but this always depends on the clinician's threshold for cystoscopy [48].

Bladder tumor antigen is a human complement factor H-related protein that is produced by malignant urothelial cells which interrupts complement activation and is considered to allow tumor cells to escape from immune surveillance [49]. BTA STAT and BTA TRAK (Polymedco, Cortlandt Manor, NY, USA) are FDA-approved tests for the detection of complement factor $\mathrm{H}$ and related proteins in voided urine and it is used for bladder cancer follow up in addition to cystoscopy. In pooled analysis of over 2000 patients, overall sensitivities and specificities were reported for BTA STAT and BTA TRAK and they were $58 \%, 71 \%$ and $73 \%, 66 \%$, respectively [50]. Sensitivity of the assays were improved with high stage and grade of tumor, however like in other non-cell based assays, specificity was lower than cytology in most studies, despite the exclusion of benign urologic conditions. Despite being 
approved by FDA for BC diagnosis, BTA STAT and BTA TRAK cannot stand for either cystoscopy nor cytology [10,11,22-25].

Recently, 14 urine proteins in voided urine samples and 10-protein bladder cancer biomarker panel, including IL8, MMP-9, MMP-10, SERPINA1, VEGFA, ANG, CA9, APOE, SDC1, and SERPINE1, were analyzed and validated in a large cohort [22-25]. A multicentre external validation study with a total of 320 subjects also validated that the diagnostic performance of the 10-biomarker panel out performed any single biomarker (AUC $=0.847$ (95\% confidence interval, 0.796-0.899). After the external validation study, a custom multiplex assay was constructed, and the analytical performance was compared with the data obtained from the individual ELISA assays. The multiplex assay was found to be rapid and had a better performance. A 10-biomarker panel including IL8, MMP-9, A1AT, ANG, VEGFA, CA9, MMP-10, APOE, PAI1, and SDC1 had the greatest diagnostic performance with an AUC of 0.888 . Urinary PAI1 was the most accurate single biomarker, followed by IL8 (AUC $=0.8335$ and 0.8489 respectively) [16].

The urinary concentrations of 14 biomarkers (IL-8, MMP-9, MMP-10, SDC1, CCL18, PAI-1, CD44, VEGF, ANG, CA9, A1AT, OPN, PTX3, and APOE) were assessed by ELISA. It was the most accurate model for BC diagnosis (sensitivity $92 \%$, specificity $97 \%$ ), but a combination of three biomarkers, IL-8, VEGF, and APOE, was also highly accurate (sensitivity $90 \%$, specificity $97 \%$ ). BTA-Trak ELISA test had a sensitivity of $79 \%$ and a specificity of $83 \%$, but urine cytology detected only $33 \%$ of BC cases [11].

Another multiplex panel analysis of proteins in urine samples of $\mathrm{BC}$, healthy controls and other samples with varying urological disorders revealed that urine concentrations of IL-8, MMP-9 and 10, PAI-1, ANG, and APOE were significantly increased in subjects with BC compared to healthy controls. Urine CA9 was significantly decreased in BC cases. IL-8, MMP-9, PAI-1 and APOE were significantly increased in high compared to low grade tumors as well as in MIBC compared to nonMIBC [18]

The protein concentrations of IL-8, MMP-9, and Syndecan were assessed by ELISA. Urinary protein concentrations of IL-8, MMP-9, and BTA were significantly elevated in BC subjects but multivariate regression analysis revealed that only IL-8 was an independent factor for the detection of BC [25].

Urine and serum matrix metalloproteinase (MMP)-2 and -9 , and tissue inhibitor of metalloproteinase (TIMP)- 1 and -2 levels were analyzed by ELISA in BC patients. Urinary TIMP-1 levels were found to be significantly higher in high grade $\mathrm{BC}$ rather than the low-grade samples $(p=0.022)$, TIMP-1 distribution was found significantly different between the Ta and T1 stage specimens $(p=0.040)$. Serum neutrophil gelatinase-associated lipocalin (NGAL) levels of non-muscle invasive (Ta and $\mathrm{T} 1)$ tumors were significantly higher than those of muscle invasive $(>\mathrm{T} 1)$ bladder cancer (MIBC) $(32.8 \mathrm{ng} / \mathrm{mL}$ vs. $16.2 \mathrm{ng} / \mathrm{mL} ; p=0.029)$. Receiver operating characteristic ROC curve analysis revealed that urinary TIMP-1 and serum NGAL may be useful non-invasive biomarkers to provide clinical information for bladder cancer disease [51].

Soluble Fas (sFas) protein expression levels in urine samples from pre-operated NMIBC patients were analyzed by ELISA and it was reported that a urinary sFas test might help to identify NMIBC patients that are at risk of tumor recurrence. The authors found that urinary sFas expression level of patients with recurrent disease was significantly higher than those without recurrent disease [38]. Urinary sFas levels and tissue VEGF protein expressions were analyzed in a prior study. They found that urinary sFas levels were significantly higher in patients with UC than in those without cancer and a positive correlation was found between the expression of VEGF protein and the pathological stage/grade in UC tissues (each $p<0.05$ ). A significant correlation was also found between sFas levels and VEGF expressions $(R=0.882, p<0.05)$. The authors conclude that $s$ Fas and VEGF may together play important roles in the occurrence, progression and diagnosis of UC [37]. Urine sFas was an independent predictor of bladder cancer recurrence and invasiveness in patients who had a history of non-muscle invasive bladder transitional cell carcinoma (TCC), and it outperformed NMP22 [52].

The expression of HER2/neu analyzed in serum and urine samples of bladder cancer patients and healthy donors. Mean serum HER2/neu values were similar between the two groups, but urinary 
HER2/neu levels were significantly higher in BC group. The ratio of urinary HER2/neu to urinary creatinine was found to be significantly higher in BC group. Even though serum and urinary HER2/ neu levels were not associated with clinical pathological factors, the ratio of urinary HER2/neu to urinary creatinine levels were significantly higher in high-grade tumors. Likewise, the ratio of urinary HER2/neu and urinary creatinine was found to be significantly higher in patients with bladder cancer and the authors conclude that a larger cohort is needed to be examined for the use of HER2/neu as a tumor marker [53].

N-Myc downstream-regulated gene 2 (NDRG2) is associated with cell differentiation and proliferation in various cancers. NDRG2 expressions were analyzed in urine samples of 127 patients with bladder cancer and 97 healthy controls and in bladder cancer cell lines by quantitative reverse transcription-polymerase chain reaction (qRT-PCR) and Western blotting. NDRG2 expression was significantly decreased in urine samples of patients with bladder cancer, both at mRNA and protein levels, also lower expressions were correlated with tumor grade and stage. It has been found that NDRG2 could be a good diagnostic marker for bladder cancer (AUC $=0.888$ ) [54].

Collagens were also analyzed for diagnostic and prognostic capabilities. Protein levels of COL4A1, COL13A1, CYFRA21-1, and NMP-22 in urine supernatants were studied and urine levels of COL4A1, COL13A1, the combined values of COL4A1 and COL13A1 (COL4A1 + COL13A1), and CYFRA21-1 were found significantly elevated in patients compared to the controls. Urinary COL4A1 + COL13A1 up-regulation was found to be an independent risk factor for intravesical recurrence [55].

\section{Urinary micro RNAs for Bladder Cancer Diagnosis}

Micro RNAs are small, around 22 nucleotides long non-protein coding RNAs that regulate gene expression [56,57]. They are synthesized and processed in the nucleus and released into cytoplasm, they can also be found in body fluids as free circulating miRNAs, bound to ribonucleoprotein complexes or in extracellular vesicles (EV), such as exosomes [58]. Figure 1 summarizes the origins of miRNAs in urine.

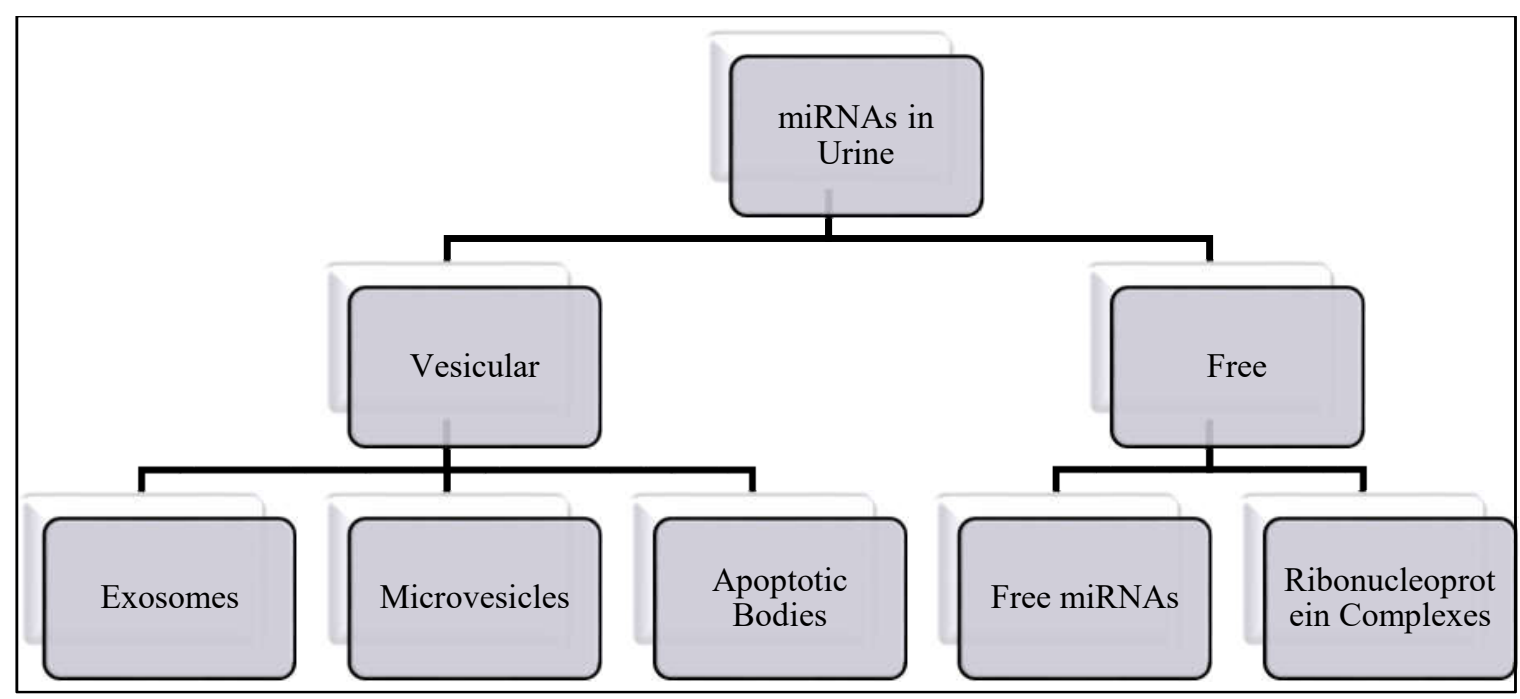

Vesicular miRNAs originate from apoptotic cells, exosomes or microvesicles. Free miRNAs either could be found as naked forms or ribonucleoprotein complexes coupled with Argonauteargonaute, $H D L$, and nucleoplasmin.

Figure 1. miRNAs in urine could be either as vesicular or free circulating miRNAs.

Since miRNAs can be found in urine EVs and they are protected from degradation, the evaluation of EV miRNA profile represents a promising diagnostic and prognostic non-invasive tool in bladder cancer. 
Andreu and colleagues analyzed 43 urine samples (34 bladder cancer, nine non-smoker healthy volunteers). Twenty six miRNAs were deregulated; most of them were significantly down regulated in high-grade bladder cancer patients compared to the healthy group, while only three miRNAs were significantly up regulated in cancer samples. let-7c, miR-30c-2, miR-146a-5p, miR-194-5p, and miR-375 were selected for further validation by qRT-PCR, miR-375 expression was significantly lower in high-grade bladder cancer patients and miR-146a was found to be significantly up regulated in low-grade bladder cancer patients. Non coding small RNAs, Let-7c and miR-194 were slightly down regulated in bladder cancer samples but the difference was not significant. Extracellular vesicle miRNAs were analyzed for recurrence, analysis show that miR-146a, miR-194, and let-7c levels are lower in recurrent low-grade cancer patients, while miR-30c-2 is up regulated in low grade relapsing cases [59]. Although promising, these results are not statistically significant; re-evaluation in a larger cohort is essential. Similarly, the significance of miR-375 and miR-146a expression differences should be verified in a larger cohort. The authors concluded that, if confirmed in a larger cohort, miR-146a could be a useful biomarker for recurrence and differentiation between high and low-grade bladder cancer patients.

Because changes in miRNA expression in cancer tissues exhibit tissue specificity with high stability and detectability, miRNA expression analysis is considered a potential biological marker for both detection and surveillance $[57,60,61]$. Yun et al. reported that miRNA-200a might have a potential to predict recurrence, however this was not validated in an independent cohort [62]. Sapre et al. reported a six miRNA panel (miRNA-16, -21, -34a, -200c, -205, -221) with an impressive ability to detect active bladder cancer ( $\mathrm{AUC}=0.85$ for the discovery cohort and 0.74 for the validation cohort). The sensitivity of the recurrence estimate was $88 \%$, the specificity was $48 \%$ and the panel showed the best performance in T1 tumors [63]. Sasaki and colleagues compared miRNA expressions of bladder cancer cell lines with normal uroepithelial tissue and identified three miRNAs (miR-301b, -563 , and $-146 a-5 p$ ) that showed $>2$-fold higher expression in cancer cell lines. Urine miRNA analysis of these three miRNAs revealed that miR-146a-5p level was significantly higher in urine samples of bladder cancer patients than healthy controls $(p=0.0014)$. Furthermore, the expression of the urine miR-146a-5p in patients with bladder cancer was reduced to the normal level after transurethral resection $(p=0.0214)$. Their results suggested that urinary miRNA-146a-5p levels might be a candidate for non-invasive diagnostic marker for bladder cancer [64]. A decrease in urinary miR-146a-5p after transurethral resection suggests that urinary miR-146a-5p is mostly originated from cancer cells and therefore miR-146a-5p is the diagnostic and prognostic biomarker for urinary bladder cancer.

Recent research revealed that miR-125b, miR-30b, miR-204, miR-99a, and miR-532-3p are significantly down regulated in patients' urine. A 381 miRNA containing array card was used to analyze urine supernatants of 46 bladder cancer patients and 13 healthy controls. Results were normalized to miR-191, miR-28-3p, and miR-200b, which were selected by the qBase+, the analysis of miR-125 levels provided the highest AUC (0.801) with $95.65 \%$ specificity and $59.26 \%$ sensitivity, and miR-99a lead to AUC (0.738) with $82.61 \%$ specificity and $74.07 \%$ sensitivity [65].

It was demonstrated that loss of miRNA-141 and miRNA-200b expression increases the invasion and migration capacities of bladder cancer cell lines and up regulates $M M P-2, M M P-9$, vimentin, $\mathrm{N}$-cadherin while down regulates E-cadherin expression. Urine analysis of these miRNAs revealed that miRNA-141 and miRNA-200b expression in urine specimens could distinguish patients with lymph node metastasis from those who were lymph node negative (AUC $=0.704$ and 0.674 , respectively) [66].

Cell-free miR-214, a secretory miRNA of bladder cancer cell lines, was reduced in urine samples of preoperative bladder cancer patients and increased expression was found in post-operative urine samples. Decreased expression of extracellular miR-214 in urine is associated with a high tumor stage, a high lymph node status, a higher grade, age, and history of NMIBC. The urinary cell free miR-214 can distinguish bladder cancer patients (AUC $=0.838 ; 95 \% \mathrm{CI}=0.796-0.875$ ) from healthy controls and can also serve as an independent prognostic predictor of recurrence-free survival (RFS) and overall survival (OS) in patients with MIBC [67]. 
Recently, Zhang and colleagues developed a direct PCR method (qRT-PCR-D) for quantification of cell-free miR-155 in urine without RNA extraction. They also tested results with qRT-PCR and found a linear correlation between the two methods. Both methods showed that cell-free miR-155 was significantly increased in NMIBC patients. Cell-free miR-155 RT-qPCR-D distinguished NMIBC patients from cystitis patients and healthy donors with $80.2 \%$ sensitivity and $84.6 \%$ specificity; this was superior to urine cytology. Cell-free miR-155 was found to be significantly decreased after transurethral bladder resection and its expression correlated with NMIBC stage and grade [68].

To compare the diagnostic performance of a 12 miRNA urine panel with cystoscopy, 81 patients profiles were analyzed. A group of six miRNAs including miR16, miR200c, miR205, miR21, miR221, and miR34a, gave the best performance to predict the presence of a tumor (AUC $=0.85$ ). Validation with further 50 patients revealed that miR 16, 21 and 200c, detected in all samples in both cohorts and 6 miRNAs, were detected in a high proportion of samples. miR-16, 200c, 205, 21,221, and 34a were over expressed in bladder cancer samples, expression data normalized to urine osmolality [63].

Eighty five urine samples were analyzed with TaqMan low-density array, 46 miRNAs were selected for validation study in a larger cohort consisting of 121 people, 61 with confirmed BC. Mamm U6 was used as an endogenous control for data normalization [69]. Multivariable analysis shows that a 25-miRNA model could predict the presence of BC with $87 \%$ sensitivity and $100 \%$ specificity. A 10 -miRNA model achieved sensitivity of $84 \%$ and specificity of $87 \%$ (AUC $=0.902$ ). Limiting the prediction models to 15 and 10 miRNAs resulted in some loss of performance. Several miRNAs (miR-140-5p, miR-199a-3p, miR-93, miR-652, miR-1305, miR-224, miR-96, miR-766) consistently contributed to all models, even though the authors conclude that the most of these core miRNAs have not been reported to be associated with $B C$ previously, this is not the first time that these miRNAs have been associated with cancer [58].

Recently miR-31-5p, miR-93-5p and miR-191-5p were analyzed in urine samples of BC patients and controls and $B C$ patients showed significantly increased expression in urine samples. miR-93-5p, miR-31-5p found to be sensitive enough to detect BC (AUC $=0.81)$ and expressed significantly different in the various histopathological subgroups of BCA, also decreased post-operatively [70].

Vascular endothelial growth factor-c mRNA and protein expression is increased in tumor tissues, blood and urine samples of BC patients. Conversely, miR-186 expressions were reduced in tumor tissues, blood and urine samples of BC patients. Dual luciferase reporter assay demonstrated that miR-186 binds to $3^{\prime}$-untranslated region of VEGF-C and regulates its expression, indicating that VEGF-C expression is over expressed in BC samples because of miR-186 down-regulation, resulting enhanced invasion and metastasis potential of BC. Direct regulation of VEGF-C by miR-186 indicates that miR-186 could be a good biomarker for BC prognosis in tissue, blood and also urine samples [71].

A comprehensive study by $\mathrm{Du}$ and colleagues analyzed and validated the diagnostic and prognostic performance of urinary cell free miRNAs for BC. Urinary miRNAs of BC samples and healthy controls first sequenced with MiSeq, candidate reference miRNAs and differentially expressed ones identified and validated with qRT-PCR. let-7b-5p and miR-532-5p are defined as the most stable pair of reference miRNAs and 23 other miRNAs defined as differentially expressed ones. Among them, five miRNAs (miR-7-5p, miR-22-3p, miR-29a-3p, miR-126-5p, and miR-375) were significantly up regulated and two (miR-200a-3p, miR-423-5p) were down regulated in BC samples compared with controls. Results validated in two independent cohorts as training set and validation set. miR-22-3p and miR-200a-3p were identified as independent factors for tumor recurrence in NMIBC. After resection of tumors, miR-22-3p and miR-29a-3p levels in the urine samples were significantly down-regulated, indicating a strong association between miR-22-3p, miR-29a-3p levels and the tumor status [72].

Eight miRNAs; miR-25-3p, miR-18a-3p, miR-92a-3p, miR-140-5p, miR-125b-5p, miR-142-3p, miR-204-5p, and miR-187-3p were analyzed in urine pellets of BC patients, evaluating urinary cell miRNAs as prognostic biomarkers of BC. With a mathematical model of linear combination two miRNA signature, miR-140-5p and miR-92a-3p, identified a subgroup of patients with a higher probability of tumor progression and shorter cancer specific survival [73]. 
We identified aberrantly expressed microRNAs in bladder cancer urine specimens by literature review $[10,58,74-76]$. We found 106 urinary miRNAs that are associated with bladder cancer (Table 2). Next, we analyzed targets of those miRNAs. According to mirBase Catalogue by Experimental Evidencesthere are 1443 target genes with strong evidence (Supplement 1 file) [77]. Catalogue includes only gene-miRNA interactions that are supported by Reporter assays. 32 of these genes are targeted by more than five miRNAs. Six miRNAs (hsa-miR-100-5p, hsa-miR-122-5p, hsa-miR-155-5p, hsa-miR-29a-3p, hsa-miR-429, and hsa-miR-21-5p) target the same 17 genes, among 32 target genes. 17 common targeted genes and miRNAs are listed on Table 3.

Table 2. Deregulated urinary miRNAs in bladder cancer.

\begin{tabular}{|c|c|c|c|c|c|}
\hline let-7b & $\operatorname{miR}-27 b$ & $\operatorname{miR}-125 b$ & miR-182 & miR-222 & miR-515 \\
\hline let-7i & miR-29a & miR-126-5p & miR-183 & miR-223 & miR-520e \\
\hline miR-1 & miR-29a-3p & miR-133a & miR-187 & miR-302d & miR-545 \\
\hline miR-7-5p & miR-34a & miR-133b & miR-191 & miR-325 & miR-556 \\
\hline miR-9-3 & miR-92a & miR-134 & miR-192 & miR-328 & miR-589 \\
\hline miR-10a & miR-93 & $\operatorname{miR}-135 b$ & miR-193a-3p & miR-328 & miR-616 \\
\hline miR-10b & miR-96 & miR-137 & miR-200a & miR-335 & miR-618 \\
\hline miR-15a & miR-99a & miR-140-5p & miR-200a-3p & $\operatorname{miR}-338-3 p$ & miR-873 \\
\hline miR-15b & miR-100 & $\operatorname{miR}-141$ & miR-200b & miR-375 & miR-890 \\
\hline miR-16 & miR-101 & miR-142-3p & miR-200c & miR-377 & miR-892a \\
\hline miR-18a & miR-106b & miR-143 & miR-203 & $\operatorname{miR}-423-5 p$ & miR-923 \\
\hline $\operatorname{miR}-18 a-3 p$ & $\operatorname{miR}-122-3 p$ & miR-145 & miR-204 & $\operatorname{miR}-424$ & miR-940 \\
\hline miR-21 & miR-122-5p & miR-146a-5p & miR-205 & $\operatorname{miR}-429$ & miR-1207-5p \\
\hline miR-22-3p & miR-124-2 & miR-148a & miR-210 & miR-451a & miR-1224 \\
\hline miR-24-1 & miR-124-3 & miR-149 & miR-211 & miR-452 & miR-1224-3p \\
\hline miR-25 & miR-1255b & miR-152 & miR-212 & $\operatorname{miR}-483-5 p$ & miR-1225-5p \\
\hline miR-26a & miR-1255b-5p & miR-155 & miR-214 & miR-505 & \\
\hline miR-27a & $\operatorname{miR}-125 a$ & miR-156 & miR-221 & miR-509 & \\
\hline
\end{tabular}

Table 3. 6 miRNAs that target 17 genes among 32 genes.

\begin{tabular}{|c|c|}
\hline Validated Target Gene & miRNA \\
\hline$B C L 2$ & \multirow{17}{*}{$\begin{array}{c}\text { hsa-miR-100-5p } \\
\text { hsa-miR-122-5p } \\
\text { hsa-miR-155-5p } \\
\text { hsa-miR-29a-3p } \\
\text { hsa-miR-429 } \\
\text { hsa-miR-21-5p }\end{array}$} \\
\hline CCND1 & \\
\hline CCND2 & \\
\hline CDK6 & \\
\hline CDKN1A & \\
\hline ERBB2 & \\
\hline IGF1R & \\
\hline MYB & \\
\hline$M Y C$ & \\
\hline PTEN & \\
\hline RECK & \\
\hline RHOA & \\
\hline SMAD4 & \\
\hline$S P 1$ & \\
\hline TP53 & \\
\hline VEGFA & \\
\hline WEE1 & \\
\hline
\end{tabular}

BCL2: Bcl2 apoptosis regulator; CCND1: Cyclin D1; CCND2: Cyclin D2; CDK6: Cyclin dependent kinase 6; CDKN1A: Cyclin dependent kinase inhibitor 1A; ERBB2: erb-b2 receptor tyrosine kinase 2; IGF1R: Insulin like growth factor 1 receptor; MYB: MYB proto-oncogene; MYC: MYC proto-oncogene; PTEN: Phosphatase and tensin homolog; RECK: Reversion inducing cysteine rich protein with kazal motifs; RHOA: Ras homolog family member A; SMAD4: SMAD family member 4; SP1: Sp1 transcription factor; TP53: Tumor protein p53; VEGFA: Vascular endothelial growth factor A; WEE1: WEE1 G2 checkpoint kinase. 
Next, the cellular pathways associated with these 17 genes were investigated by the Panther Database [78]. 17 genes: BCL2, CCND1, CCND2, CDK6, CDKN1A, ERBB2, IGF1R, MYB, MYC, PTEN, RECK, RHOA, SMAD4, SP1, TP53, VEGFA, and WEE1 are components of different cellular pathways. The main pathways and components are CCKR pathway (BCL2, CCND1, MYC, PTEN, RHOA, SP1), p53 pathway, feedback loops (CDKN1A, MYC, PTEN, TP53) and Wnt signaling pathway (CCND1, MYC, SMAD4, TP53).

Other pathways include angiogenesis, cell cycle, fibroblast growth factor (FGF) signaling pathway, IGF-Mapk cascade, the full list is given in the Supplement 1 file.

Cholecystokinin receptor (CCKR) signaling pathway is triggered by CCK1R and CCK2R, which then influence the expression of downstream genes that affect cell survival, angiogenesis and invasion. p53 pathway regulates the cell cycle, inhibits angiogenesis, and promotes growth arrest, apoptosis, and DNA repair. The Wnt signaling pathway is a signal transduction pathway that pass signals into a cell through cell surface receptors and activates multiple signaling pathways in a cell. Wnt signaling results in transcriptional activation of Wnt target genes and controls cancer stemness. These pathways are related to cell survival, apoptosis, and invasion. But the fact that the WNT pathway controls the stemness suggests that miRNAs related to the WNT pathway may be examined for treatment response. miRNAs which associated with the WNT pathway would be more important for the treatment response while CCKR and p53 pathway associated miRNAs are more promising for the diagnosis.

\section{Conclusions}

To conclude, urinary proteins and miRNAs are promising biomarkers for non-invasive bladder cancer diagnosis and prognosis. To date, urinary IL-8, MMP-9 and VEGF, miR-200 family, miR-146 and miR-155 were found to be strongest putative urinary markers. Increased expressions in BC samples and decrease in urinary concentrations after transurethral resection suggests that urinary miR-146a and 155 are mostly originated from cancer cells. However, there are some deficiencies in the methods, overcoming these will lead to a new era for non-invasive bladder cancer diagnosis. ELISA is a widely used method for the analysis of proteins in the urine, either total protein or creatinine concentration is used for normalization and different normalization strategies can affect the results. RNU-48, miR-16, U-6, or total RNA concentrations could be used for normalization in analysis of urine miRNA concentrations, but stable expression of urinary microRNAs in the healthy individuals has not yet been fully explored. Housekeeping miRNAs in the urine should be analyzed in multicentre, large cohort studies and the diagnostic value of urinary miRNAs should be reassessed, because inappropriate normalization causes unreliable results. Urinary protein and microRNA expressions that are isolated and normalized by standardized methods will be highly valuable in terms of non-invasive diagnosis of bladder cancer.

Another issue that should be standardized in the use of urine biomarkers for bladder cancer is the collection and storage of urine specimens until analysis; different groups collect and store samples under different conditions. Some groups collect the first urination in the morning, some prefer any urination during the day, and some collect after bladder stimulation massage. Some groups centrifuge the urine samples before storage at high speed, while some groups use low speed to remove cell debris. Although some studies state that urine fraction does not affect the outcome, use of single or multiple biomarkers does; the lack of homogeneity in terms of urine fraction is also worth considering [79].

Different urine fractions were used in different studies. miR-126, 182, 520e, 618, 122-5p, 16, 21, 34a, 200c, 205, and 211 were found to be up regulated in whole urine samples [53,80-82]. Urine sediments are also widely used for miRNA analysis, miR-96, 183, 15b, 1224-3p, 222, 452, 141, 200a/b/c, 18a, $25,187,92 \mathrm{a}, 210$, and 141 are up regulated in urine sediments of bladder cancer patients $[63,83-86]$. The urine fraction to be used should be well assessed, along with several advantages relative to each other. Numerous population studies will contribute to the development of urinary biomarkers in which, protein, and miRNA expressions are examined in different urinary fractions where a high 
number of patients and volunteers are involved. These studies will be the beginning of a new era in non-invasive diagnosis and follow-up of bladder cancer.

Supplementary Materials: The following are available online at http:/ /www.mdpi.com/2076-3271/6/4/113/s1, Table S1: Targets of miRNAs. According to "mirBase Catalogue by Experimental Evidences" there are 1443 target genes with strong evidence; Table S2: Cellular pathways associated with target genes were investigated by the Panther Database.

Funding: This research was funded Marmara University BAPKO No.: SAG-C-DRP-131016-0441 and SAG-C-DRP-110117-0015.

Conflicts of Interest: The authors declare that they have no conflict of interest.

\section{References}

1. Bray, F.; Ferlay, J.; Soerjomataram, I.; Siegel, R.L.; Torre, L.A.; Jemal, A. Global cancer statistics 2018: GLOBOCAN estimates of incidence and mortality worldwide for 36 cancers in 185 countries. CA Cancer J. Clin. 2018, 68, 394-424. [CrossRef] [PubMed]

2. NICE. Bladder cancer: Diagnosis and management of bladder cancer. BJU Int. 2017, 120, 755-765. [CrossRef] [PubMed]

3. Antoni, S.; Ferlay, J.; Soerjomataram, I.; Znaor, A.; Jemal, A.; Bray, F. Bladder Cancer Incidence and Mortality: A Global Overview and Recent Trends. Eur. Urol. 2017, 71, 96-108. [CrossRef] [PubMed]

4. Chen, Y.; Chen, C.; Chen, H.; Chung, T.; Wu, C.; Chen, C.; Hsu, C.; Chen, M.; Tsui, K.; Chang, P.; et al. Discovery of Novel Bladder Cancer Biomarkers by Comparative Urine Proteomics Using iTRAQ Technology research articles. J. Proteome Res. 2010, 9, 5803-5815. [CrossRef] [PubMed]

5. Li, H.; Li, C.; Wu, H.; Zhang, T.; Wang, J.; Wang, S.; Chang, J. Identification of Apo-A1 as a biomarker for early diagnosis of bladder transitional cell carcinoma. Proteome Sci. 2011, 9, 21. [CrossRef] [PubMed]

6. Tan, W.S.; Tan, W.P.; Tan, M.Y.; Khetrapal, P.; Dong, L.; DeWinter, P.; Feber, A.; Kelly, J.D. Novel urinary biomarkers for the detection of bladder cancer: A systematic review. Cancer Treat. Rev. 2018, 69, 39-52. [CrossRef]

7. Mbeutcha, A.; Lucca, I.; Mathieu, R.; Lotan, Y.; Shariat, S.F. Current Status of Urinary Biomarkers for Detection and Surveillance of Bladder Cancer. Urol. Clin. N. Am. 2016, 43, 47-62. [CrossRef] [PubMed]

8. Yeung, C.; Dinh, T.; Lee, J. The Health Economics of Bladder Cancer: An Updated Review of the Published Literature. PharmacoEconomics 2014, 32, 1093-1104. [CrossRef] [PubMed]

9. Lavery, H.J.; Zaharieva, B.; McFaddin, A.; Heerema, N.; Pohar, K.S. A prospective comparison of UroVysion FISH and urine cytology in bladder cancer detection. BMC Cancer 2017, 17, 247. [CrossRef] [PubMed]

10. Liu, X.; Liu, X.; Wu, Y.; Wu, Q.; Wang, Q.; Yang, Z.; Li, L. MicroRNAs in biofluids are novel tools for bladder cancer screening. Oncotarget 2017, 8, 32370-32379. [CrossRef]

11. Goodison, S.; Chang, M.; Dai, Y.; Urquidi, V.; Rosser, C.J. A multi-analyte assay for the non-invasive detection of bladder cancer. PLoS ONE 2012, 7, e47469. [CrossRef] [PubMed]

12. Ho, M.E.; Quek, S.-I.; True, L.D.; Seiler, R.; Fleischmann, A.; Bagryanova, L.; Kim, S.R.; Chia, D.; Goodglick, L.; Shimizu, Y.; et al. Bladder cancer cells secrete while normal bladder cells express but do not secrete AGR2. Oncotarget 2016, 7, 15747-15756. [CrossRef] [PubMed]

13. Blanca, A.; Requena, M.J.; Alvarez, J.; Cheng, L.; Montironi, R.; Raspollini, M.R.; Reymundo, C.; Lopez-Beltran, A. FGFR3 and Cyclin D3 as urine biomarkers of bladder cancer recurrence. Biomark. Med. 2016, 10, 243-253. [CrossRef] [PubMed]

14. D'Costa, J.J.; Goldsmith, J.C.; Wilson, J.S.; Bryan, R.T.; Ward, D.G. A Systematic Review of the Diagnostic and Prognostic Value of Urinary Protein Biomarkers in Urothelial Bladder Cancer. Bladder Cancer 2016, 2, 301-317. [CrossRef] [PubMed]

15. Heit, C.; Jackson, B.C.; McAndrews, M.; Wright, M.W.; Thompson, D.C.; Silverman, G.A.; Nebert, D.W.; Vasiliou, V. Update of the human and mouse SERPIN gene superfamily. Hum. Genom. 2013, 7, 22. [CrossRef] [PubMed]

16. Shimizu, Y.; Furuya, H.; Bryant Greenwood, P.; Chan, O.; Dai, Y.; Thornquist, M.D.; Goodison, S.; Rosser, C.J. A multiplex immunoassay for the non-invasive detection of bladder cancer. J. Transl. Med. 2016, 14, 31. [CrossRef] [PubMed] 
17. Chatzileontiadou, D.S.M.; Samiotaki, M.; Alexopoulou, A.N.; Cotsiki, M.; Panayotou, G.; Stamatiadi, M.; Balatsos, N.A.A.; Leonidas, D.D.; Kontou, M. Proteomic analysis of human angiogenin interactions reveals cytoplasmic PCNA as a putative binding partner. J. Proteome Res. 2017, 16, 3606-3622. [CrossRef]

18. Rosser, C.J.; Ross, S.; Chang, M.; Dai, Y.; Mengual, L.; Zhang, G.; Kim, J.; Urquidi, V.; Alcaraz, A.; Goodison, S. Multiplex protein signature for the detection of bladder cancer in voided urine samples. J. Urol. 2013, 190, 2257-2262. [CrossRef]

19. Mangaraj, M.; Nanda, R.; Panda, S. Apolipoprotein A-I: A Molecule of Diverse Function. Indian J. Clin. Biochem. 2016, 31, 253-259. [CrossRef]

20. Mahley, R.W. Apolipoprotein E: Cholesterol transport protein with expanding role in cell biology. Science 1988, 240, 622-630. [CrossRef]

21. Chen, L.M.; Chang, M.; Dai, Y.; Chai, K.X.; Dyrskjøt, L.; Sanchez-Cabayo, M.; Szarvas, T.; Zwarthoff, E.C.; Lokeswhar, V.; Jeronimo, C.; et al. External validation of a multiplex urinary protein panel for the detection of bladder cancer in a multicenter cohort. Cancer Epidemiol. Biomark. Prev. 2014, 23, 1804-1812. [CrossRef] [PubMed]

22. Urquidi, V.; Kim, J.; Chang, M.; Dai, Y.; Rosser, C.J.; Goodison, S. CCL18 in a multiplex urine-based assay for the detection of bladder cancer. PLoS ONE 2012, 7, e37797. [CrossRef]

23. Urquidi, V.; Goodison, S.; Ross, S.; Chang, M.; Dai, Y.; Rosser, C.J. Diagnostic Potential of Urinary

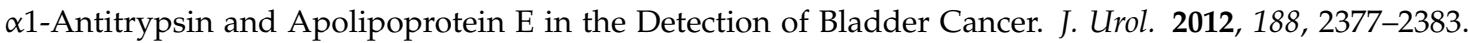
[CrossRef] [PubMed]

24. Urquidi, V.; Goodison, S.; Kim, J.; Chang, M.; Dai, Y.; Rosser, C.J. Vascular endothelial growth factor, carbonic anhydrase 9, and angiogenin as urinary biomarkers for bladder cancer detection. Urology 2012, 79, 1185.e1-1185.e6. [CrossRef] [PubMed]

25. Urquidi, V.; Chang, M.; Dai, Y.; Kim, J.; Wolfson, E.D.; Goodison, S.; Rosser, C.J. IL-8 as a urinary biomarker for the detection of bladder cancer. BMC Urol. 2012, 12, 12. [CrossRef] [PubMed]

26. Andreucci, E.; Peppicelli, S.; Carta, F.; Brisotto, G.; Biscontin, E.; Ruzzolini, J.; Bianchini, F.; Biagioni, A.; Supuran, C.T.; Calorini, L. Carbonic anhydrase IX inhibition affects viability of cancer cells adapted to extracellular acidosis. J. Mol. Med. 2017, 95, 1341-1353. [CrossRef] [PubMed]

27. Adema, G.J.; Hartgers, F.; Verstraten, R.; Vries, E.; Marland, G.; Menon, S.; Foster, J.; Xu, Y.; Nooyen, P.; McClanahan, T.; et al. A dendritic-cell-derived C-C chemokine that preferentially attracts naive T cells. Nature 1997, 387, 713-717. [CrossRef] [PubMed]

28. Basakran, N.S. CD44 as a potential diagnostic tumor marker. Saudi Med. J. 2015, 36, 273-279. [CrossRef] [PubMed]

29. Alfaro, C.; Sanmamed, M.F.; Rodríguez-Ruiz, M.E.; Teijeira, Á.; Oñate, C.; González, Á.; Ponz, M.; Schalper, K.A.; Pérez-Gracia, J.L.; Melero, I. Interleukin-8 in cancer pathogenesis, treatment and follow-up. Cancer Treat. Rev. 2017, 60, 24-31. [CrossRef]

30. Rodriguez, J.A. Metalloproteinases and atherothrombosis: MMP-10 mediates vascular remodeling promoted by inflammatory stimuli. Front. Biosci. 2008, 13, 2916. [CrossRef]

31. Nossier, A.I.; Mohammed, O.S.; Fakhr El-deen, R.R.; Zaghloul, A.S.; Eissa, S. Gelatin-modified gold nanoparticles for direct detection of urinary total gelatinase activity: Diagnostic value in bladder cancer. Talanta 2016, 161, 511-519. [CrossRef] [PubMed]

32. Coppola, D.; Szabo, M.; Boulware, D.; Muraca, P.; Alsarraj, M.; Chambers, A.F.; Yeatman, T.J. Correlation of Osteopontin Protein Expression and Pathological Stage across a Wide Variety of Tumor Histologies. Clin. Cancer Res. 2004, 10, 184-190. [CrossRef] [PubMed]

33. Vaughan, D.E.; Rai, R.; Khan, S.S.; Eren, M.; Ghosh, A.K. Plasminogen Activator Inhibitor-1 Is a Marker and a Mediator of Senescence. Arterioscler. Thromb. Vasc. Biol. 2017, 37, 1446-1452. [CrossRef] [PubMed]

34. Wingfield, P.T.; Palmer, I.; Liang, S.M. Folding and purification of insoluble (inclusion body) proteins from Escherichia coli. Curr. Protoc. Protein Sci. 2014, 2014, 6.5.1-6.5.30. [CrossRef]

35. Baietti, M.F.; Zhang, Z.; Mortier, E.; Melchior, A.; Degeest, G.; Geeraerts, A.; Ivarsson, Y.; Depoortere, F.; Coomans, C.; Vermeiren, E.; et al. Syndecan-syntenin-ALIX regulates the biogenesis of exosomes. Nat. Cell Biol. 2012, 14, 677-685. [CrossRef]

36. Miyake, M.; Lawton, A.; Dai, Y.; Chang, M.; Mengual, L.; Alcaraz, A.; Goodison, S.; Rosser, C.J. Clinical implications in the shift of syndecan-1 expression from the cell membrane to the cytoplasm in bladder cancer. BMC Cancer 2014, 14, 86. [CrossRef] 
37. Yang, H.; Wang, Z.; Guo, Y.; Wang, Z. Correlation and Significance of Urinary Soluble Fas and Vascular Endothelial Growth Factor in Bladder Urothelial Cancer. Dis. Markers 2015, 2015, 1-5. [CrossRef]

38. Yang, H.; Guo, Y.; Wang, Z.; Wang, Z. Value of detection of preoperative urinary soluble Fas expression in predicting the recurrence of non-muscle invasive bladder cancer. J. Cent. South Univ. Med. Sci. 2016, 41, 24-29.

39. Meiron, M.; Anunu, R.; Scheinman, E.J.; Hashmueli, S.; Levi, B.Z. New isoforms of VEGF are translated from alternative initiation CUG codons located in its 5'UTR. Biochem. Biophys. Res. Commun. 2001, 282, 1053-1060. [CrossRef]

40. Kośliński, P.; Daghir-Wojtkowiak, E.; Szatkowska-Wandas, P.; Markuszewski, M.; Markuszewski, M.J. The metabolic profiles of pterin compounds as potential biomarkers of bladder cancer-Integration of analytical-based approach with biostatistical methodology. J. Pharm. Biomed. Anal. 2016, 127, 256-262. [CrossRef]

41. Chen, Y.T.; Chen, H.W.; Domanski, D.; Smith, D.S.; Liang, K.H.; Wu, C.C.; Chen, C.L.; Chung, T.; Chen, M.C.; Chang, Y.S.; et al. Multiplexed quantification of 63 proteins in human urine by multiple reaction monitoring-based mass spectrometry for discovery of potential bladder cancer biomarkers. J. Proteom. 2012, 75, 3529-3545. [CrossRef]

42. Chen, C.L.; Lin, T.S.; Tsai, C.H.; Wu, C.C.; Chung, T.; Chien, K.Y.; Wu, M.; Chang, Y.S.; Yu, J.S.; Chen, Y.T. Identification of potential bladder cancer markers in urine by abundant-protein depletion coupled with quantitative proteomics. J. Proteom. 2013, 85, 28-43. [CrossRef] [PubMed]

43. Goodison, S.; Ogawa, O.; Matsui, Y.; Kobayashi, T.; Miyake, M.; Ohnishi, S.; Fujimoto, K.; Dai, Y.; Shimizu, Y.; Tsukikawa, K.; et al. A multiplex urinary immunoassay for bladder cancer detection: Analysis of a Japanese cohort. J. Transl. Med. 2016, 14, 287. [CrossRef] [PubMed]

44. Li, F.; Yu, Z.; Chen, P.; Lin, G.; Li, T.; Hou, L.; Du, Y.; Tan, W. The increased excretion of urinary orosomucoid 1 as a useful biomarker for bladder cancer. World Health 2016, 6, 331-340.

45. Choi, S.; Shin, J.H.; Lee, Y.R.; Joo, H.K.; Song, K.H.; Na, Y.G.; Chang, S.J.; Lim, J.S.; Jeon, B.H. Urinary APE1/Ref-1: A Potential Bladder Cancer Biomarker. Dis. Markers 2016, 2016. [CrossRef] [PubMed]

46. Jamshidian, H.; Kor, K.; Djalali, M. Urine concentration of nuclear matrix protein 22 for diagnosis of transitional cell carcinoma of bladder. Urol. J. 2008, 5, 243-247.

47. Lotan, Y.; Capitanio, U.; Shariat, S.F.; Hutterer, G.C.; Karakiewicz, P.I. Impact of clinical factors, including a point-of-care nuclear matrix protein-22 assay and cytology, on bladder cancer detection. BJU Int. 2009, 103, 1368-1374. [CrossRef]

48. Shariat, S.F.; Savage, C.; Chromecki, T.F.; Sun, M.; Scherr, D.S.; Lee, R.K.; Lughezzani, G.; Remzi, M.; Marberger, M.J.; Karakiewicz, P.I.; et al. Assessing the clinical benefit of nuclear matrix protein 22 in the surveillance of patients with nonmuscle-invasive bladder cancer and negative cytology. Cancer 2011, 117, 2892-2897. [CrossRef]

49. Kinders, R.; Jones, T.; Root, R.; Bruce, C.; Murchison, H.; Corey, M.; Williams, L.; Enfield, D.; Hass, G.M. Complement factor $\mathrm{H}$ or a related protein is a marker for transitional cell cancer of the bladder. Clin. Cancer Res. 1998, 4, 2511-2520.

50. Rhijn, B.W.G.; Poel, H.G.; Kwast, T.H. Urine markers for bladder cancer surveillance: A systematic review. Eur. Urol. 2005, 47, 736-748. [CrossRef]

51. Ricci, S.; Bruzzese, D.; Carlo, A. Evaluation of MMP-2, MMP-9, TIMP-1, TIMP-2, NGAL and MMP-9/NGAL complex in urine and sera from patients with bladder cancer. Oncol. Lett. 2015, 10, 2527-2532. [CrossRef] [PubMed]

52. Svatek, R.S.; Herman, M.P.; Lotan, Y.; Casella, R.; Hsieh, J.-T.; Sagalowsky, A.I.; Shariat, S.F. Soluble Fas-A promising novel urinary marker for the detection of recurrent superficial bladder cancer. Cancer 2006, 106. [CrossRef] [PubMed]

53. Arikan, O.; Yýldýrým, A.; Ýsbilen, B.; Canakci, C.; Atýs, G.; Gurbuz, C.; Erol, B.; Ýsman, F.K.; Ozkanli, S.; Caskurlu, T. Clinical significance of serum and urinary HER2/neu protein levels in primary non-muscle invasive bladder cancer. Int. Braz. J. Urol. 2015, 41, 1080-1087. [CrossRef] [PubMed]

54. Zhang, M.; Ren, B.; Li, Z.; Niu, W.; Wang, Y. Expression of N-Myc Downstream-Regulated Gene 2 in Bladder Cancer and Its Potential Utility as a Urinary Diagnostic Biomarker. Med. Sci. Monit. Int. Med. J. Exp. Clin. Res. 2017, 23, 4644-4649. [CrossRef] 
55. Miyake, M.; Morizawa, Y.; Hori, S.; Tatsumi, Y.; Onishi, S.; Owari, T.; Iida, K.; Onishi, K.; Gotoh, D.; Nakai, Y.; et al. Diagnostic and prognostic role of urinary collagens in primary human bladder cancer. Cancer Sci. 2017, 108, 2221-2228. [CrossRef]

56. Ambros, V. The functions of animal microRNAs. Nature 2004, 431, 350-355. [CrossRef] [PubMed]

57. Bartel, D.P. MicroRNAs: Genomics, biogenesis, mechanism, and function. Cell 2004, 116, 281-297. [CrossRef]

58. Fendler, A.; Stephan, C.; Yousef, G.M.; Kristiansen, G.; Jung, K. The translational potential of microRNAs as biofluid markers of urological tumours. Nat. Rev. Urol. 2016, 13, 734-752. [CrossRef]

59. Andreu, Z.; Oshiro, R.O.; Redruello, A.; López-Martín, S.; Gutiérrez-Vázquez, C.; Morato, E.; Marina, A.I.; Gómez, C.O.; Yáñez-Mó, M. Extracellular vesicles as a source for non-invasive biomarkers in bladder cancer progression. Eur. J. Pharm. Sci. 2016, 98, 70-79. [CrossRef]

60. Krabbe, L.M.; Woldu, S.L.; Shariat, S.F.; Lotan, Y. Improving diagnostic molecular tests to monitor urothelial carcinoma recurrence. Expert Rev. Mol. Diagn. 2016, 16, 1189-1199. [CrossRef]

61. Chen, X.; Ba, Y.; Ma, L.; Cai, X.; Yin, Y.; Wang, K.; Guo, J.; Zhang, Y.; Chen, J.; Guo, X.; et al. Characterization of microRNAs in serum: A novel class of biomarkers for diagnosis of cancer and other diseases. Cell Res. 2008, 18, 997-1006. [CrossRef] [PubMed]

62. Yun, S.J.; Jeong, P.; Kim, W.T.; Kim, T.H.; Lee, Y.S.; Song, P.H.; Choi, Y.H.; Kim, I.Y.; Moon, S.K.; Kim, W.J. Cell-free microRNAs in urine as diagnostic and prognostic biomarkers of bladder cancer. Int. J. Oncol. 2012, 41, 1871-1878. [CrossRef]

63. Sapre, N.; Macintyre, G.; Clarkson, M.; Naeem, H.; Cmero, M.; Kowalczyk, A.; Anderson, P.D.; Costello, A.J.; Corcoran, N.M.; Hovens, C.M. A urinary microRNA signature can predict the presence of bladder urothelial carcinoma in patients undergoing surveillance. Br. J. Cancer 2016, 114, 454-462. [CrossRef] [PubMed]

64. Sasaki, H.; Yoshiike, M.; Nozawa, S.; Usuba, W.; Katsuoka, Y.; Aida, K.; Kitajima, K.; Kudo, H.; Hoshikawa, M.; Yoshioka, Y.; et al. Expression Level of Urinary MicroRNA-146a-5p Is Increased in Patients with Bladder Cancer and Decreased in Those After Transurethral Resection. Clin. Genitourin. Cancer 2016, 14, e493-e499. [CrossRef] [PubMed]

65. Pospisilova, S.; Pazzourkova, E.; Horinek, A.; Brisuda, A.; Svobodova, I.; Soukup, V.; Hrbacek, J.; Capoun, O.; Hanus, T.; Mares, J.; et al. MicroRNAs in urine supernatant as potential non-invasive markers for bladder cancer detection. Neoplasma 2016, 63, 799-808. [CrossRef] [PubMed]

66. Liu, W.; Qi, L.; Lv, H.; Zu, X.; Chen, M.; Wang, J.; Liu, L.; Zeng, F.; Li, Y. MiRNA-141 and miRNA-200b are closely related to invasive ability and considered as decision-making biomarkers for the extent of PLND during cystectomy. BMC cancer 2015, 15, 92. [CrossRef] [PubMed]

67. Wang, J.; Zhang, X.; Wang, L.; Dong, Z.; Du, L.; Yang, Y.; Guo, Y.; Wang, C. Downregulation of urinary cell-free microRNA-214 as a diagnostic and prognostic biomarker in bladder cancer. J. Surg. Oncol. 2015, 111, 992-999. [CrossRef] [PubMed]

68. Zhang, X.; Zhang, Y.; Liu, X.; Fang, A.; Wang, J.; Yang, Y.; Wang, L.; Du, L.; Wang, C. Direct quantitative detection for cell-free miR-155 in urine: A potential role in diagnosis and prognosis for non-muscle invasive bladder cancer. Oncotarget 2016, 7, 3255-3266. [CrossRef]

69. Urquidi, V.; Netherton, M.; Gomes-Giacoia, E.; Serie, D.J.; Eckel-Passow, J.; Rosser, C.J.; Goodison, S. A microRNA biomarker panel for the non-invasive detection of bladder cancer. Oncotarget 2016, 5. [CrossRef]

70. Juracek, J.; Peltanova, B.; Dolezel, J.; Fedorko, M.; Pacik, D.; Radova, L.; Vesela, P.; Svoboda, M.; Slaby, O.; Stanik, M. Genome-wide identification of urinary cell-free microRNAs for non-invasive detection of bladder cancer. J. Cell. Mol. Med. 2018, 22, 2033-2038. [CrossRef]

71. He, X.; Ping, J.; Wen, D. MicroRNA-186 regulates the invasion and metastasis of bladder cancer via vascular endothelial growth factor C. Exp. Ther. Med. 2017, 14, 3253-3258. [CrossRef] [PubMed]

72. Du, L.; Duan, W.; Jiang, X.; Zhao, L.; Li, J.; Wang, R.; Yan, S.; Xie, Y.; Yan, K.; Wang, Q.; et al. Cell-free lncRNA expression signatures in urine serve as novel non-invasive biomarkers for diagnosis and recurrence prediction of bladder cancer. J. Cell. Mol. Med. 2018, 22, 2838-2845. [CrossRef] [PubMed]

73. Ingelmo-Torres, M.; Lozano, J.J.; Izquierdo, L.; Carrion, A.; Costa, M.; Gómez, L.; Ribal, M.J.; Alcaraz, A.; Mengual, L. Urinary cell microRNA-based prognostic classifier for non-muscle invasive bladder cancer. Oncotarget 2017, 8, 18238-18247. [CrossRef] [PubMed]

74. Dong, F.; Xu, T.; Shen, Y.; Zhong, S.; Chen, S.; Ding, Q.; Shen, Z. Dysregulation of miRNAs in bladder cancer: Altered expression with aberrant biogenesis procedure. Oncotarget 2015, 8, 27547-27568. [CrossRef] [PubMed] 
75. Enokida, H.; Yoshino, H.; Matsushita, R.; Nakagawa, M. The role of microRNAs in bladder cancer. Cell 2016, 57, 60-76. [CrossRef] [PubMed]

76. Lee, J.-Y.; Ryu, D.-S.; Kim, W.-J.; Kim, S.-J. Aberrantly expressed microRNAs in the context of bladder tumorigenesis. Investig. Clin. Urol. 2016, 57 (Suppl. 1), S52-S59. [CrossRef] [PubMed]

77. Chou, C.H.; Shrestha, S.; Yang, C.D.; Chang, N.W.; Lin, Y.L.; Liao, K.W.; Huang, W.C.; Sun, T.H.; Tu, S.J.; Lee, W.H.; et al. MiRTarBase update 2018: A resource for experimentally validated microRNA-target interactions. Nucleic Acids Res. 2018, 46, D296-D302. [CrossRef] [PubMed]

78. Mi, H.; Huang, X.; Muruganujan, A.; Tang, H.; Mills, C.; Kang, D.; Thomas, P.D. PANTHER version 11: Expanded annotation data from Gene Ontology and Reactome pathways, and data analysis tool enhancements. Nucleic Acids Res. 2017, 45, D183-D189. [CrossRef] [PubMed]

79. Kutwin, P.; Konecki, T.; Borkowska, E.M.; Traczyk-Borszyńska, M.; Jabłonowski, Z. Urine miRNA as a potential biomarker for bladder cancer detection-A meta-analysis. Cent. Eur. J. Urol. 2018, 71, 177-185. [CrossRef]

80. Tölle, A.; Jung, M.; Rabenhorst, S.; Kilic, E.; Jung, K.; Weikert, S. Identification of microRNAs in blood and urine as tumour markers for the detection of urinary bladder cancer. Oncol. Rep. 2013, 30, 1949-1956. [CrossRef] [PubMed]

81. Snowdon, J.; Boag, S.; Feilotter, H.; Izard, J.; Siemens, D.R. A pilot study of urinary microRNA as a biomarker for urothelial cancer. J. Can. Urol. Assoc. 2013, 7, 28-32. [CrossRef]

82. Hanke, M.; Hoefig, K.; Merz, H.; Feller, A.C.; Kausch, I.; Jocham, D.; Warnecke, J.M.; Sczakiel, G. A robust methodology to study urine microRNA as tumor marker: MicroRNA-126 and microRNA-182 are related to urinary bladder cancer. Urol. Oncol. 2010, 28, 655-661. [CrossRef] [PubMed]

83. Yamada, Y.; Enokida, H.; Kojima, S.; Kawakami, K.; Chiyomaru, T.; Tatarano, S.; Yoshino, H.; Kawahara, K.; Nishiyama, K.; Seki, N.; et al. MiR-96 and miR-183 detection in urine serve as potential tumor markers of urothelial carcinoma: Correlation with stage and grade, and comparison with urinary cytology. Cancer Sci. 2011, 102, 522-529. [CrossRef] [PubMed]

84. Miah, S.; Dudziec, E.; Drayton, R.M.; Zlotta, A.R.; Morgan, S.L.; Rosario, D.J.; Hamdy, F.C.; Catto, J.W.F. An evaluation of urinary microRNA reveals a high sensitivity for bladder cancer. Br. J. Cancer 2012, 107, 123-128. [CrossRef] [PubMed]

85. Wang, G.; Chan, E.S.Y.; Kwan, B.C.H.; Li, P.K.T.; Yip, S.K.H.; Szeto, C.C.; Ng, C.F. Expression of microRNAs in the urine of patients with bladder cancer. Clin. Genitourin. Cancer 2012, 10, 106-113. [CrossRef] [PubMed]

86. Mengual, L.; Lozano, J.J.; Ingelmo-Torres, M.; Gazquez, C.; Ribal, M.J.; Alcaraz, A. Using microRNA profiling in urine samples to develop a non-invasive test for bladder cancer. Int. J. Cancer 2013, 133, 2631-2641. 